\title{
Editorial for Business Research 13(1)
}

\author{
Thomas Gehrig ${ }^{1}$
}

Published online: 30 March 2020

(C) The Author(s) 2020

\section{March 2020}

In line with the expansion strategy that Business Research has entered in the year 2017, the composition and the structure of the Departments have changed. Specifically the Department of Operations and Information Systems has been split into two, with the Department of Operations, which will be continued to be directed by Thomas Spengler, and the new separated Department of Information Systems.

We welcome Tilo Böhmann for taking over the responsibilities for the new Department of Information Systems starting this January 2020! We also welcome Jana Oehmichen and Elke Schüßler! Ms. Schüßler succeeded Thomas Hutzschenreuter already in 2019. Since January 2020, she and Ms. Oehmichen share the responsibilities for our largest and most heterogeneous Department of Management. We are most grateful to Thomas Hutzschenreuter for his diligent service over two appointment periods and for his generous contributions and advice to the Editorial Team of Business Research!

The expansion strategy has already produced excellent results in its first 2 years of operation. We have increased the number of published manuscripts continuously from 12 in 2016 to 25 in 2019. Certainly, the Special Issue 12(1) on the theme of the Magdeburg Annual VHB Conference in 2018, “(Ir)Rationality in Business Research and Practice" was an important driver in this regard, and contributed to visibility and impact as evidenced by a spectacular increase in downloads and citations overall. Critical mass and open access are the keys to this success. We are hopeful that the Special Issue "Digital Transformation" dedicated to the governing theme of this year's Annual VHB Conference in Frankfurt will be an equally successful venture.

Thomas Gehrig

thomas.gehrig@univie.ac.at

1 Department of Finance, University of Vienna, Oskar-Morgenstern-Platz 1, 1090 Wien, Austria 
With all that tailwind and momentum, I am happy to announce the next stage of our strategy, the creation of a large international open access journal in business research. As has been announced by the Boards of the German Academic Association for Business Research (VHB) and the Schmalenbach Gesellschaft (SG) at the Frankfurt Annual VHB Conference, the two associations will join forces and merge their research publication platforms to generate a strong common journal with international reach, the Schmalenbach Journal of Business Research-SBUR.

Building on the momentum of our open access accomplishments, we are convinced that the merger will add even more critical mass necessary for a strong journal in the international academic market. With the support and the expertise of two large and esteemed academic associations, $S B U R$ will be able to continue to serve all sub-disciplines of business administration, including methodological and policy-making support about business research, and, thus, follow and carry over a long tradition of excellent research in business into the future digital open science world.

Details about $S B U R$ and submissions for $S B U R$ will be communicated shortly on the homepages of both the VHB and the SG. They will also be communicated in the next Editorial of Volume 13(2).

\author{
On behalf of the Editorial Team \\ Thomas Gehrig \\ Editor-in-Chief
}

Open Access This article is licensed under a Creative Commons Attribution 4.0 International License, which permits use, sharing, adaptation, distribution and reproduction in any medium or format, as long as you give appropriate credit to the original author(s) and the source, provide a link to the Creative Commons licence, and indicate if changes were made. The images or other third party material in this article are included in the article's Creative Commons licence, unless indicated otherwise in a credit line to the material. If material is not included in the article's Creative Commons licence and your intended use is not permitted by statutory regulation or exceeds the permitted use, you will need to obtain permission directly from the copyright holder. To view a copy of this licence, visit http:// creativecommons.org/licenses/by/4.0/. 